\title{
Total RNA Extraction from the Aromatic Phalaenopsis bellina, Endemic Orchid in Sabah, Borneo
}

\author{
Ahmad Asnawi MUS ${ }^{1}$, Jualang Azlan GANSAU ${ }^{2}$ and Nor Azizun RUSDI ${ }^{3, *}$ \\ ${ }^{1}$ Institute for Tropical Biology and Conservation, Universiti Malaysia Sabah, Sabah, Malaysia \\ ${ }^{2}$ Faculty of Science and Natural Resources, Universiti Malaysia Sabah, Sabah, Malaysia \\ ${ }^{3}$ Unit for Orchid Studies, Institute for Tropical Biology and Conservation, University Malaysia Sabah, \\ Sabah, Malaysia
}

('Corresponding author's e-mail: azizun@ums.edu.my)

Received: 16 March 2019, Revised: 30 July 2019, Accepted: 12 August 2019

\begin{abstract}
Phalaenopsis bellina is an attractive orchid due to its unique appearance and distinctive floral fragrance. Many past studies on this plant focused on the plant at the molecular level; however, this requires sufficient quantities of high-quality $P$. bellina RNA. RNA is more delicate to manipulate than DNA due to its structural instability and its vulnerability to various secondary metabolites, such as polyphenols and polysaccharides. Therefore, in this study, 4 RNA isolation methods, a modified phenolchloroform method and 3 commercial kits (Vivantis, Novogene, and Analytik Jena) were used on the leaves and flowers of $P$. bellina for comparison. The yield and purity of the total RNA were determined using spectrophotometry. The results showed that the total RNA isolated using the modified phenolchloroform method had the highest yield $(1223.75 \pm 68.51 \mathrm{ng} / \mu \mathrm{L})$ and purity compared to the 3 commercial kits, with an OD260/280 value of 2.07 and an OD260/230 value of 2.26 , respectively. In particular, the isolated RNA did not show any detectable genomic DNA contamination or other impurities. The RNA isolated using the phenol-chloroform method was also evaluated by electrophoresis, reverse transcription, and PCR. The results indicated that the phenol-chloroform method appears to be superior for total RNA extraction. Thus, this developed method is proven to be suitable for the RNA extraction of plants rich in polysaccharides and polyphenols and is amenable for future molecular studies on P. bellina.
\end{abstract}

Keywords: Phalaenopsis bellina, Orchidaceae, RNA, Phenol-chloroform, Isolation, Flower

\section{Introduction}

Phalaenopsis bellina, commonly known as the "Lundu orchid" or "Norma orchid", is an orchid endemic to Borneo [1]. The word Bellina is derived from the Latin word Bella, which means beauty or lovely [2]. The name befits its unique appearance, where the flower is brightly colored in white, greenishwhite, yellow or, on rare occasions, orange tepals with an intense magenta blotch on the inner halves of the lateral sepals. Apart from its distinct floral appearance, the flower also emits a strong-sweet fragrance, with a hint of lemony and citrusy odors $[3,4]$. Due to its unique characteristics, $P$. bellina is often used as a parent for the breeding of scented hybrid cultivars [5].

Many of the molecular studies conducted on $P$. bellina revolved around the biosynthesis of the fragrance in the P. bellina flowers. To our knowledge, Hsiao et al. [6] was the first author who attempted to elucidate the fragrance in $P$. bellina. The researchers had conducted chemical profiling, along with gas chromatography mass spectrometry (GC-MS), the identification of floral expressed sequence tags (EST), and bioinformatics analysis. The authors managed to pinpoint $66 \%$ of the biosynthetic steps from glyceraldehyde-3-phosphate (G3P) to the production of various fragrance derivatives, particularly that of 
http://wjst.wu.ac.th

geraniol and linalool. Through cDNA cloning and protein characterization, Hsiao et al. [7] managed to isolate geranyl diphosphate synthase from the $P$. bellina flower (PbGDPS), a protein involved as a precursor to the production of various monoterpenes. PbGDPS was in turn regulated by several regulatory elements, which are PbbZIP4 and PbbHLH4, previously isolated by Chuang et al. [8] and Chuang et al. [9], respectively.

High-quality Ribonucleic Acid (RNA) must be extracted for studies on gene expression in plants. Reverse Transcription-Polymerase Chain Reaction (RT-PCR), Complementary Deoxyribonucleic Acid (cDNA) synthesis, and subsequent genetic analysis also require RNA with high purity and integrity [10]. However, obtaining high quality RNA from plant samples remains difficult. The presence of polysaccharides, polyphenols, lipids, and other secondary metabolites that may bind to the nucleic acids during extraction may interfere with subsequent molecular studies [11-14]. A large number of plantspecific RNA extraction protocols have been highlighted. All of these methods recommend a diversity of strategies to isolate sufficient RNA from plants, depending on a plant's species condition [15].. Liu et al. [10] managed to isolate total RNA from Dendrobium huoshansense, an orchid that is known to have high levels of polysaccharides and polyphenols, using methods modified from those of Chan et al. [16]. Meanwhile, Abd Rahman et al. [17] managed to isolate the RNA from mangosteen (Garcinia mangostana L.) and screened it for RNA sequencing suitability. Compared to Liu et al.'s work [10], the method developed by Abd Rahman et al. [17] required 3 days of complete extraction, which is longer and time-consuming. Das et al. [18] optimized an RNA extraction method on tea roots (Camellia sinensis) based on sodium dodecyl sulphate (SDS) for the construction of the plant's cDNA library. Ma and Yang [19] attempted to isolate RNA from the dry seeds of the sunflower (Helianthus annuus) using RNAiso, RNAiso Plus + RNAiso-mate, and Trizol kits. However, no total RNA of high quality was obtained.

To our knowledge, no protocol has been developed for the optimized RNA extraction of $P$. bellina. Therefore, the leaves and flowers of $P$. bellina were selected as the subjects of total RNA extraction by applying the modified phenol-chloroform method, as well as 3 other extraction kits (Vivantis, Analytik Jena, and Novogene). RNA extraction method suitability was chosen based on RNA purity ratio (A260/A280 and A260/230), gel electrophoresis, and PCR assessment.

\section{Materials and methods}

Orchid collection and maintenance

Phalaenopsis bellina orchid was brought from local vendors and maintained in the Institute for Tropical Biology and Conservation (ITBC) greenhouse, Universiti Malaysia Sabah. The orchid's flowers and leaves were collected from April to October 2018. Harvested flowers and leaf samples were kept in liquid nitrogen before being stored at $-80^{\circ} \mathrm{C}$ for further use.

Total RNA extraction

RNA was extracted from the leaves and flowers of $P$. bellina. Three commercial kits were used [Analytik Jena (Germany), Vivantis (Malaysia), and Novelgene (Singapore)] according to each respective manufacturer's instruction. A brief overview of methods used by each kit is summarized in Table $\mathbf{1}$. 
http://wjst.wu.ac.th

Table 1 Overview of methods used by the 3 kits for total RNA extraction.

\begin{tabular}{llll}
\hline Steps/Brand & Analytik Jena & Vivantis & Novelgene \\
\hline Cell lysis & $\begin{array}{l}\text { Uses readymade lysis } \\
\text { buffer }\end{array}$ & $\begin{array}{l}\text { Uses readymade lysis buffer } \\
\text { and } \beta \text {-mercaptoethanol } \\
\text { Included in the kit }\end{array}$ & $\begin{array}{l}\text { Uses readymade lysis buffer } \\
\text { and } \beta \text {-mercaptoethanol } \\
\text { Not included in the kit }\end{array}$ \\
$\begin{array}{l}\text { Removal of genomic DNA } \\
\text { gDNA) }\end{array}$ & $\begin{array}{l}\text { Utilizes different column } \\
\text { Selective binding of RNA }\end{array}$ & $\begin{array}{l}\text { Utilizes different column } \\
\text { (RNA binding column) }\end{array}$ & $\begin{array}{l}\text { The same column used in the } \\
\text { whole process } \\
\text { Ethanol-based washing buffer }\end{array}$ \\
Washing of bound RNA & $\begin{array}{l}\text { Ethanol-based washing } \\
\text { buffer } \\
\text { Guanidinium thiocyanate } \\
\text { and guanidinium chloride }\end{array}$ & $\begin{array}{l}\text { Ethanol-based washing } \\
\text { buffer } \\
\text { Guanidinium thiocyanate }\end{array}$ & Guanidinium thiocyanate \\
\hline
\end{tabular}

Manual RNA extraction was done by adapting methods loosely from Lewis et al. [20] with slight modifications. Concentration of $\mathrm{LiCl}$ was increased to $4 \mathrm{M}$ instead of $2 \mathrm{M}$ for total RNA precipitation, while total genomic DNA was completely removed using ethanol precipitation twice. Approximately 0.25 $\mathrm{g}$ of $P$. bellina petals or leaves were ground into powder in liquid nitrogen. The powdered sample was then quickly transferred into a falcon tube (Fischer, Malaysia) containing $5 \mathrm{~mL}$ of extraction buffer [250 $\mathrm{mM}$ (Tris-Hydrochloric acid) (Tris-HCl) (pH 7.5), $375 \mathrm{mM}$ of Sodium Chloride (NaCl) (Sigma Aldrich, USA), $25 \mathrm{mM}$ of Ethylenediaminetetraacetate disodium salt dihydrate $\left(\mathrm{Na}_{2} \mathrm{EDTA}\right)(\mathrm{pH}$ 8.0) (Sigma Aldrich, USA), $1 \%(\mathrm{w} / \mathrm{v})$ of SDS (Sigma Aldrich, USA), and $1 \%(\mathrm{v} / \mathrm{v})$ of $\beta$-mercaptoethanol) (Sigma Aldrich, USA)], and was vortexed immediately for $15 \mathrm{~s}$. Then, $3 \mathrm{~mL}$ of phenol (Sigma Aldrich, USA) was added and it was vortexed again for $15 \mathrm{~s}$. This was followed by the addition of $3 \mathrm{~mL}$ chloroform:isoamyl alcohol (24:1, v/v) (Sigma Aldrich, USA) and it was vortexed for $15 \mathrm{~s}$. Then, the sample was centrifuged for $10 \mathrm{~min}$ at 5000 rotations per min (rpm). Aqueous or top phase obtained was transferred into a new tube and $3 \mathrm{~mL}$ of phenol:chloroform (1:1, v/v) (Sigma Aldrich, USA) was added. The sample was vortexed for $15 \mathrm{~s}$ and centrifuged for $10 \mathrm{~min}$ at 5,000 rpm using ultracentrifuge (Thermo Scientific, USA). The aqueous or top phase obtained was transferred into a new tube containing $8 \mathrm{~mL}$ of $4 \mathrm{M} \mathrm{LiCl}$ (Sigma Aldrich, USA) to precipitate total nucleic acid. The sample was then incubated in -20 ${ }^{\circ} \mathrm{C}$ overnight to maximize nucleic acid precipitation.

After the overnight incubation, the sample was centrifuged at $7,000 \mathrm{rpm}$ for $30 \mathrm{~min}$ at $4{ }^{\circ} \mathrm{C}$ to pellet out the total nucleic acid. The supernatant was then removed and the tube was dried on a paper towel for $10 \mathrm{~min}$. Then, the nucleic acid pellet was resuspended in $500 \mu \mathrm{L}$ of $0.1 \%$ DEPC-treated deionized water. The sample was centrifuged again at 3,000 rpm for $5 \mathrm{~min}$ to pellet the insoluble material. The supernatant obtained was then transferred into a microcentrifuge tube containing $500 \mu \mathrm{L}$ of $4 \mathrm{M} \mathrm{LiCl}$ (Sigma Aldrich, USA). The mixture was mixed well and incubated at $4{ }^{\circ} \mathrm{C}$ overnight to precipitate the RNA.

After overnight incubation, the sample was centrifuged at 13,200 rpm for $15 \mathrm{~min}$ at room temperature to pellet total RNA. $500 \mu \mathrm{L}$ of $70 \%$ (v/v) ethanol (Sigma Aldrich, USA) was added, and then it was centrifuged again for $15 \mathrm{~min}$ at 13,200 rpm. The supernatant was removed and the ethanol step was repeated twice. Finally, the RNA pellet was air-dried for $10 \mathrm{~min}$ and dissolved in $50 \mu \mathrm{L}$ of $0.1 \%$ DEPC-treated deionized water. The RNA sample was then kept in $-80{ }^{\circ} \mathrm{C}$ for future use.

\section{RNA analysis}

The total RNA extracted from the leaves and flowers of $P$. bellina was tested for integrity using $1 \%$ Weight over Volume (w/v) agarose gel (Sigma Aldrich, USA) at 120V for $30 \mathrm{~min}$. The A260/230 and A260/280 values for the RNA sample were measured using the Implen Nanophotometer ${ }^{\circledR}$ P-Class (Implen, Germany) to evaluate the RNA purity and yield. 


\section{First strand cDNA synthesis and PCR amplification}

Approximately $2 \mu \mathrm{g}$ of RNA was used for the first strand cDNA synthesis using the Viva cDNA synthesis kit (Vivantis, Malaysia) according to its manufacturer's instruction. Two types of primers OligoDT (18) and a gene-specific primer were used. The candidate gene from the terpene synthase group was mined from Genebank's database. The full-length nucleotide sequence of Phalaenopsis equestris's terpene synthase gene (ascension number: EU124717.1) was used as a reference gene. The primer design was carried out using idtDNA tools and the Primer 3 software for specific PCR amplification. The forward primer of the terpene synthase used was 5'- TGT AAT GGA GAT TCA GCC ATC TTC - 3', while the reverse primer was 5'-TAC TAC CAC TTT GAC AAA ATA JGT TCC-3'.

PCR amplifications were carried out using degenerate primer pairs designed for the gene reference of $P$. equestris. A total reaction volume of $12.5 \mu \mathrm{L}$, containing $6.75 \mu \mathrm{L}$ of GoTaq® Green Master Mix (Promega), $0.5 \mu \mathrm{L}$ of $10 \mu \mathrm{M}$ forward and reverse primer, and $2 \mu \mathrm{L}$ cDNA, was used. Amplifications were performed in a thermocycler (Applied Biosystem, USA) and programmed as follows: initial denaturation at $94{ }^{\circ} \mathrm{C}$ for $2 \mathrm{~min}, 30$ cycles at $94{ }^{\circ} \mathrm{C}$ for $30 \mathrm{~s}, 56{ }^{\circ} \mathrm{C}$ for $30 \mathrm{~s}$, then $72{ }^{\circ} \mathrm{C}$ for $2 \mathrm{~min}$. A total of $5 \mu \mathrm{L}$ of the PCR product was separated on $1.0 \%$ agarose gel containing SYBR Safe $(0.01 \% \mathrm{v} / \mathrm{v})$ (Thermo Fischer, USA) and TBE buffer ( $1 \times)$ at $100 \mathrm{~V}$ for $30 \mathrm{~min}$. Gels were visualized under UV light and photographed with a gel image analyzer (Applegen, USA). $1 \mathrm{~Kb}$ of DNA ladder (Invitrogen, USA) was used for base pair size estimation. The remaining products were stored at $-20{ }^{\circ} \mathrm{C}$.

\section{Results and discussion}

Although RNA isolation is considered a routine protocol, the extraction of RNA from aromatic plants could be critical due to the presence of large amounts of polysaccharides, polyphenols, and other secondary metabolites which limit the RNA extraction yield and purity [21]. There are many published RNA isolation protocols of which the single-step method using guanidine isothiocyanate [22] has proven to be the most useful in model plants, i.e., rice [23] and Arabidopsis [24]. The usage of guanidinium isothiocyanate could inhibit RNA activity, but it is not quite suitable for plant tissues rich in polysaccharides and phenolics [25].

Table 2 Quantitative analysis of total RNA extraction from flowers and leaves of $P$. bellina.

\begin{tabular}{|c|c|c|c|c|c|c|}
\hline Sample & Method/kit & $\begin{array}{l}\text { Column } \\
\text { based? }\end{array}$ & $\begin{array}{c}\text { Yield }(n g / \mu \mathrm{L}) \\
\text { for } 50 \mu \mathrm{L} \\
\text { sample } \\
\end{array}$ & $\mathbf{A}_{260} / \mathbf{A}_{280}$ & $\mathbf{A}_{260} / \mathbf{A}_{230}$ & $\begin{array}{c}\text { Total time } \\
\text { required }\end{array}$ \\
\hline \multirow{4}{*}{ Flowers } & ${ }^{\mathrm{C}} \mathrm{AJ}$ & Yes & $32.33 \pm 2.52$ & $1.88 \pm 0.25$ & $0.091 \pm 0.01$ & $2 \mathrm{~h}$ \\
\hline & ${ }^{2} \mathrm{~V}$ & Yes & $264.67 \pm 4.62$ & $2.09 \pm 0.01$ & $2.39 \pm 0.01$ & $1 \frac{1}{2} \mathrm{~h}$ \\
\hline & ${ }^{3} \mathrm{NV}$ & Yes & N/A & N/A & N/A & Half day \\
\hline & $\begin{array}{l}\text { Modified phenol- } \\
\text { chloroform }\end{array}$ & No & $1223.75 \pm 68.51$ & $2.07 \pm 0.00$ & $2.26 \pm 0.05$ & 3 days \\
\hline \multirow{4}{*}{ Leaves } & ${ }^{1} \mathrm{AJ}$ & Yes & $15.0 \pm 8.66$ & N/A & $0.16 \pm 0.09$ & $2 \mathrm{~h}$ \\
\hline & ${ }^{2} \mathrm{~V}$ & Yes & $41.33 \pm 0.58$ & $2.54 \pm 0.06$ & $0.08 \pm 0.00$ & $1 \frac{1}{2} \mathrm{~h}$ \\
\hline & ${ }^{3} \mathrm{NV}$ & Yes & $11.3 \pm 0.58$ & $6.67 \pm 0.85$ & $0.62 \pm 0.02$ & Half day \\
\hline & $\begin{array}{l}\text { Modified phenol- } \\
\text { chloroform }\end{array}$ & No & $249.75 \pm 3.50$ & $1.95 \pm 0.10$ & $2.13 \pm 0.11$ & 3 days \\
\hline
\end{tabular}

${ }^{* 1} \mathrm{AJ}=$ Analytik Jena, Germany, ${ }^{2} \mathrm{~V}=$ Vivantis, Malaysia, and ${ }^{3} \mathrm{NV}=$ Novelgene, Singapore

*Data represent mean $\pm \mathrm{SD}$ of 3 replicates 
http://wjst.wu.ac.th

The RNA extraction from flowers was done using a modified phenol-chloroform method adapted from Lewis et al. [20] and 3 other commercial kits (AJ, V, and NV) (Table 2). Of all methods conducted, the AJ and V kits, along with the modified phenol-chloroform method, managed to isolate the total RNA from the $P$. bellina flowers at acceptable A260/A280 values. However, the AJ commercial kit did not manage to get full purity according to its A260/A230 reading, and the total RNA extracted appeared to be degraded (Figure 1). Although the V commercial kit had managed to obtain an acceptable total RNA yield with satisfactory A260/A280 and A260/230 values, no bands or smears were observed. The modified phenol-chloroform method managed to get the highest total RNA with suitable A260/A280 and A260/230 values. The NV kit did not manage to isolate the total RNA from the $P$. bellina flowers.

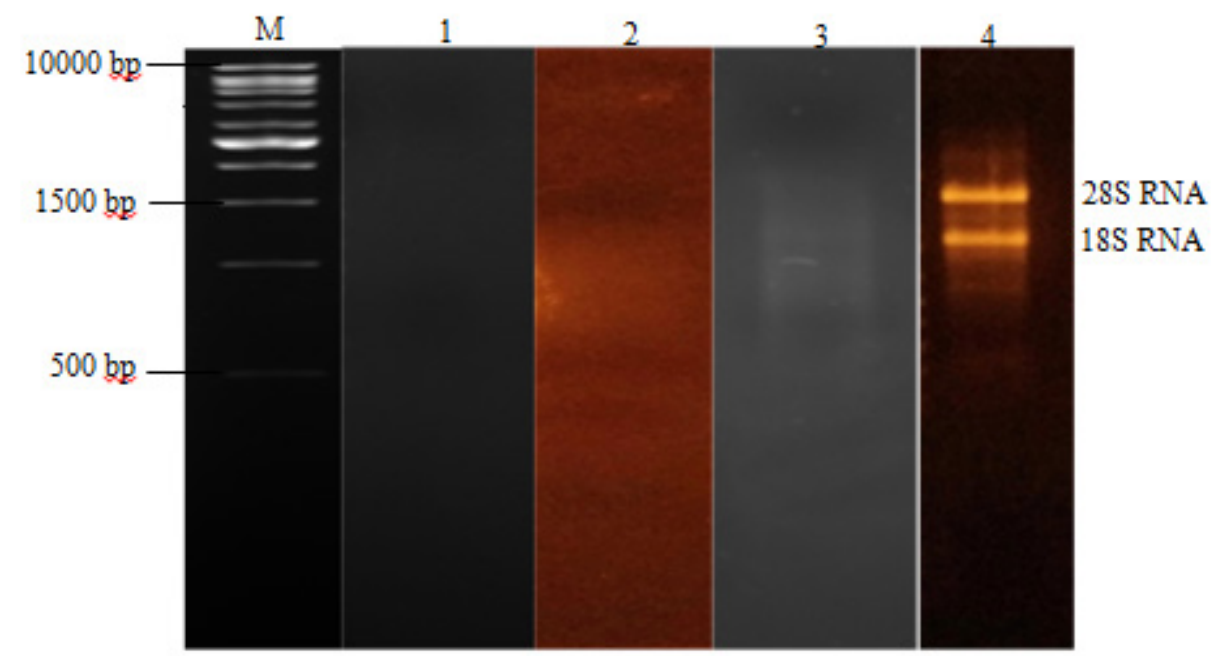

Figure 1 Qualitative results of total RNA extracted from flower tissue of $P$. bellina using different methods. Lane M: $1 \mathrm{~kb}$ DNA ladder. Lane 1: using the commercial kit NV. Lane 2: using the commercial kit V. Lane 3: using the commercial kit AJ. Lane. 4: using the modified phenol-chloroform method.

Apart from the flowers, total RNA was also extracted from the $P$. bellina's leaves. All methods had managed to isolate the total RNA from the leaves. The AJ and NV kits yielded low total RNA values from the leaves; their A260/A280 and A260/230 values were too high or low, thus indicating contamination. The total RNA extracted using the AJ kit also appeared to be degraded when visualized under gel electrophoresis (Figure 2). While the V kit managed to isolate the total RNA from the leaves at a moderate yield, no bands were observed. The same goes for the NV kit. Compared to the other methods, the modified phenol-chloroform method managed to isolate the highest total RNA yield from the leaves $(249.75 \pm 3.50)$ with satisfactory A260/A280 and A260/230 values. 
http://wjst.wu.ac.th

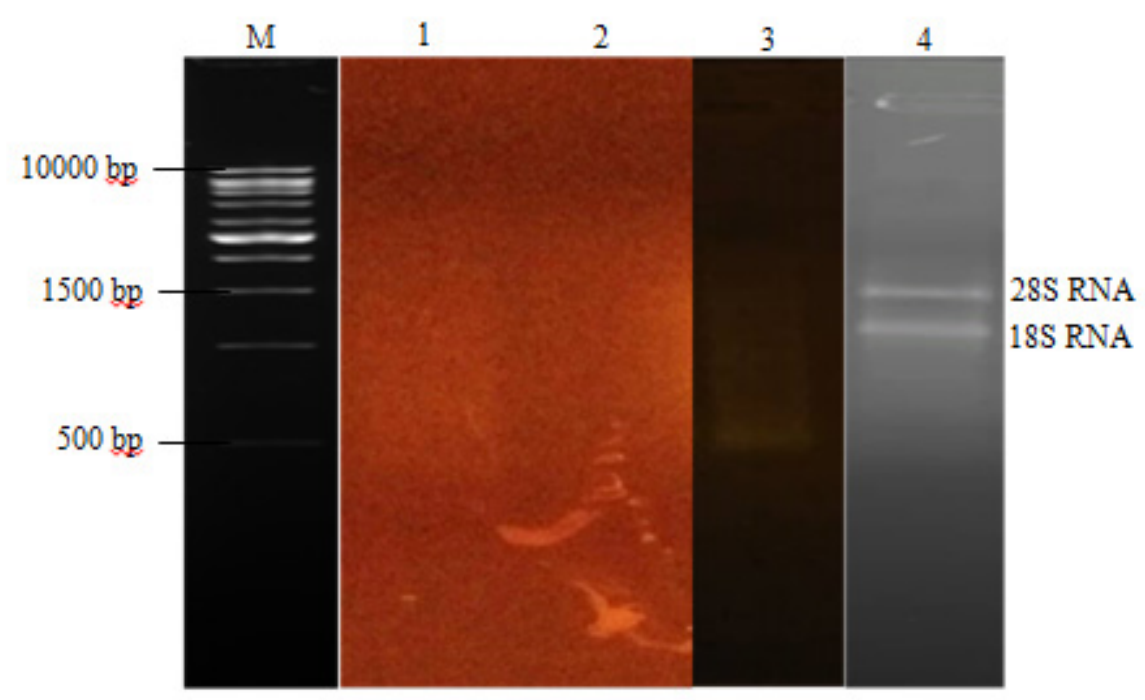

Figure 2 Qualitative results of total RNA extracted from leaf tissue of $P$. bellina using different methods. Lane M: $1 \mathrm{~kb}$ DNA ladder. Lane 1: using the commercial kit NV. Lane 2: using the commercial kit V. Lane 3: using the commercial kit AJ. Lane 4: using the modified phenol-chloroform method.

All of the commercial kits (AJ, V, and NV) used column-based technologies that resulted in low RNA yield. The column-based technologies employed created other problems, which included the complicated manipulation of buffers while loading and washing, or sensitivity problems due to nonspecific binding to the solid phase membrane provided in the column [17]. The manual method used was loosely modified from Lewis et al. [20] who had utilized phenol-chloroform extraction. The use of the extraction buffer containing EDTA acted as a chelating agent to sequester divalent cations, thereby inhibiting the deoxyribonuclease (DNase), ribonuclease (RNase), and enzyme activity to prevent the rapid degradation of the RNA. $\mathrm{NaCl}$ was used to control the lysate $\mathrm{pH}$ and create osmotic pressure [26]. Meanwhile, SDS used in the extraction acted as a detergent that effectively broke down the cell membrane [27]. $\beta$-mercaptoethanol was also used in the extraction buffer to counter oxidation [25] and eliminate RNases [28].

The use of the phenol and phenol-chloroform methods takes advantage of the nucleic acid structure. Nucleic acids have a negative charge due to their phosphate backbones, making them soluble in aqueous solutions. Proteins, lipids, and carbohydrates, on the other hand, have hydrophobic and hydrophilic domains, making them soluble in organic solutions or selective for the interface between the organic and the aqueous phases generated during the extraction process. In phenol extraction, phenol is added to an aqueous solution containing cellular constituents. The mixture and subsequent centrifugations separate the phases. At neutral or near-neutral $\mathrm{pH}$, nucleic acids remain in the aqueous phase. RNA may be selectively extracted in an acidic environment because the phosphate groups of DNA are preferentially neutralized, and the DNA is thus trapped in the organic phase [29]. Elkins [30] also stated that the usage of phenol can further degrade DNA. Chloroform:isoamyl alcohol was used in between phenol and phenol:chloroform to separate the aqueous and organic phases and prevent foaming during centrifugation [31].

Nucleic acid (DNA and RNA) structures which contain phosphate groups cause the nucleic acids to act as negatively-charged polar molecules; therefore, they possess hydrophilic characteristics. This makes them completely insoluble in alcohols. To selectively precipitate RNA, lithium chloride has been used due to its ability to precipitate RNA and remove polysaccharides [17]. 
http://wjst.wu.ac.th

In terms of total time required, the modified phenol-chloroform method required 3 days to yield the RNA, compared to the commercial kits, which required less than a day. Tüzmen et al. [26] stated that the use of the phenol-chloroform method is indeed laborious, time-consuming, and generates toxic waste. However, the total RNA yield from both the leaves and flowers of the P. bellina was high compared to the commercial kits used. The total RNA extracted from the $P$. bellina flowers was higher than from its leaf and more noticeable when visualized under agarose gel electrophoresis than the latter. Liu et al. [10] suggested that the water content of each plant structure (leaf and flower) is one of the factors contributing to the quality of total RNA. Although this method was tedious, it is interesting to know that Liu et al. [10] have also developed a high-quality RNA extraction method for Dendrobium huoshansense which only takes 2 and a half $\mathrm{h}$ and utilizes reagents that are almost similar to the method developed in this research, such as the composition of extraction buffer, and the usage of phenol:chloroform $(1: 1, \mathrm{v} / \mathrm{v}), \beta$ mercaptoethanol, and $\mathrm{LiCl}$ for RNA precipitation. Meanwhile, Abd Rahman et al. [17] took 3 days to isolate total RNA from Garcinia mangostana. It should be noted that different species require different RNA extraction protocols due to the diversity in plant structure and secondary metabolite content.

Since flowers contain the highest RNA yield, the total RNA from $P$. bellina flowers was used for reverse transcription to synthesize the cDNA and subsequent PCR (Figure 3). The cDNA can be amplified to obtain a target fragment of $650 \mathrm{bp}$ when synthesizing cDNA using gene-specific primer or when synthesizing a cDNA using OligoDT (18). This shows that the total RNA extracted using the modified phenol-chloroform method can meet the requirements of related molecular biological researches.

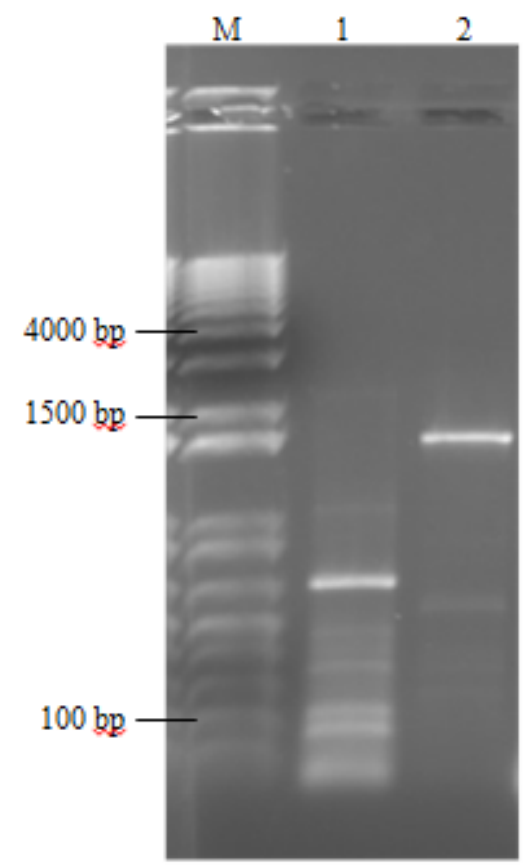

Figure 3 PCR amplification of cDNA. Lane M: 1kb DNA ladder. Lane 1: cDNA synthesized using genespecific reverse primer (the same primer was also used for PCR). Lane 2: cDNA synthesized using OligoDT (18). 
http://wjst.wu.ac.th

\section{Conclusions}

By using the modified phenol-chloroform method, the total RNA from the leaves and flowers of Phalaenopsis bellina can be extracted at high yield and quality, although the method is time-consuming and laborious. It is hoped that this study can be applied in further molecular studies on Phalaenopsis bellina.

\section{Acknowledgements}

This study was conducted with support from Fundamental Research Grant Scheme (FRG04662017) from the Ministry of Higher Education (MOHE), Malaysia, and UMS GREAT Research Grant (GUG0280-2/2018) from Universiti Malaysia Sabah. The authors also express gratitude to all who were directly and indirectly involved in this study.

\section{References}

[1] TB Beaman, JJ Wood, RS Beaman and JH Beaman. Orchids of Sarawak. Natural History Publications (Borneo) Sdn. Bhd., Kota Kinabalu, Sabah, Malaysia, 2001, p. 8-12.

[2] AB Martin. The Vocabulary of Orchids: An Amateur Perpective. Australia, 2005, p. 116.

[3] EA Christenson and MW Whitten. Phalaenopsis bellina (Rchb.f.) Christenson, A Segregate from $P$. violacea Witte (Orchidaceae: Aeridinae). Brittonia 1995; 47, 57-60.

[4] M Mahmood and YF Chew. Agrobacterium-mediated genetic transformation of Phalaenopsis bellina using GFP and GUS reporter genes. Pertanika J. Sci. Technol. 2008; 16, 129-39.

[5] YC Chuang, MC Lee, YL Chang, WH Chen and HH Chen. Diurnal regulation of the floral scent emission by light and circadian rhythm in the Phalaenopsis orchids. Bot. Stud. 2017; 58, 50.

[6] YY Hsiao, WC Tsai, CS Kuoh, TH Huang, HC Wang, TS Wu, YL Leu, WH Chen and HH Chen. Comparison of transcripts in Phalaenopsis bellina and Phalaenopsis equestris (Orchidaceae) flowers to deduce monoterpene biosynthesis pathway. BMC Plant. Biol. 2006; 6, 14.

[7] YY Hsiao, MF Jeng, WC Tsai, YC Chuang, CY Li, TS Wu, CS Kuoh, WH Chen and HH Chen. A novel homodimeric geranyl diphosphate synthase from the orchid Phalaenopsis bellina lacking a DD(X)2-4D motif. Plant J. 2008; 55, 719-33.

[8] YC Chuang, YC Hung, CY Hsu, CM Yeh, N Mitsuda, M Ohme-Takagi, WC Tsai, WH Chen and HH Chen. A dual repeat cis-element determines the expression of geranyl diphosphate synthase for monoterpene production in Phalaenopsis orchids. Front Plant. Sci. 2018; 9, 765.

[9] YC Chuang, YC Hung, WC Tsai, WH Chen and HH Chen. PbbHLH4 regulates floral monoterpene biosynthesis in Phalaenopsis orchids. J. Exp. Bot. 2018; 69, 4363-77.

[10] L Liu, R Han, N Yu, W Zhang, L Xing, D Xie and D Peng. A method for extracting high-quality total RNA from plant rich in polysaccharides and polyphenols using Dendrobium huoshanse. PloS One 2018; 13, e0196592.

[11] DV Jobes, DL Hurley and LB Thien. Plant DNA isolation: A methodology to efficiently remove polyphenolics, polysaccharides and RNA. Taxon 1995; 44, $379 \quad-86$.

[12] Y Pico de Coaña, N Parody, E Fernández-Caldas and C Alonso. A modified protocol for RNA isolation from high polysaccharide containing Cupressus arizonica pollen: Applications for RTPCR and phage display library construction. Mol. Biotechnol. 2010; 44, 127-32.

[13] KK Sharma, M Lavanya and V Anjaiah. A method for isolation and purification of peanut genomic DNA suitable for analytical applications. Plant Mol. Biol. Rep. 2000; 18, 393,

[14] D Yin, H Liu, X Zhang and D Cui. A protocol for extraction of high-quality RNA and DNA from peanut plant tissues. Mol. Biotechnol. 2011; 49, 187-91.

[15] E Macrae. Extraction of Plant RNA. In: E Hilario and J Mackay (Eds.). Molecular Biology. Vol 353. Protocols for Nucleic Acid Analysis by Nonradioactive Probes. $2^{\text {nd }}$ (eds). Humana Press, Totowa, New Jersey, USA, 2007, p. 15-26.

[16] Kam-Lock Chan, CL Ho and P Namasivayam. A simple and rapid method for RNA isolation from plant tissues with high phenolic compounds and polysaccharides. Nat. Protoc. 2007; 2007, 184. 
http://wjst.wu.ac.th

[17] A Abdul-Rahman, NI Suleman, WA Zakaria, HH Goh, NM Noor and WM Aizat. RNA extractions of mangosteen (Garcinia mangostana L.) pericaps for sequencing. Sains Malays. 2017; 46, 123140.

[18] A Das, D Saha and TP Mondal. An optimized method for extraction of RNA from teat roots for functional genomics analysis. Indian J. Biotechnol. 2013, 12, 129-32.

[19] XB Ma and J Yang. An optimized preparation method to obtain high-quality RNA from dry sunflower seeds. Genet. Mol. Res. 2011; 10, 160-8.

[20] MS Lewis, DJ Pikaard, M Nasrallah, JH Doelling and CS Pikaard. Locus specific ribosomal RNA gene silencing in nucleolar dominance. PLoS One 2007; 2, e815.

[21] SN Palani, S Elangovan, A Menon, M Kumariah and J Tennyson. An efficient nucleic acids extraction protocol for Elettaria cardamomum. Biocatal. Agric. Biotechnol. 2019; 17, 207-12.

[22] P Chomzynski and N Sacchi. Single step method of RNA isolation by acid guanidium thiocyanatephenol-chloroform extraction. Anal. Biochem. 1987; 162, 156-9.

[23] P Azizi, MY Rafili, M Mahmood, SNA Abdullah, MM Hanafi, MA Latif, M Sahebi and S Ashkani. Evaluation of RNA extraction methods in rice and their application in expression analysis of resistance genes against Magnaporthe oryzae. Biotechnol. Biotechnol. Equip. 2017; 31, 1-10.

[24] L Meng and L Feldman. A rapid TRIzol-based two-step method for DNA-free RNA extraction from Arabidopsis siliques and dry seeds. Biotechnol. J. 2010; 5, 183-6.

[25] C Shu, S Sun, J Chen, J Chen and E Zhou. Comparison of different methods for total RNA extraction from sclerotia of Rhizoctonia solani. Electron. J. Biotechnol. 2014; 17, 50-4.

[26] Ş Tüzmen, Y Baskin, A Feyda Nursal, S Eraslan, Y Esemen, G Çalibaşi, AB Demir, D Abbasoglu and C Hizel. Chapter 14 - Techniques for Nucleic Acid Engineering: The Foundation of Gene Manipulation. In: D Barh and V Azevedo (Eds.). Omics Technologies and Bio-engineering, Academic Press, India, 2018, p. 247-315.

[27] JM Butler. Chapter 2 - DNA Extraction Methods. In: JM Butler (Eds.). Advanced Topics in Forensic DNA Typing: Methodology. Academic Press, San Diego, California, 2012, p. 29-47.

[28] L Jaakola, AM Pirttilä, M Halonen and A Hohtola. Isolation of high quality RNA from bilberry (Vaccinium myrtillus L.) fruit. Mol. Biotechnol. 2001; 19, 201-3.

[29] DH Farkas and CA Holland. Chapter 3 - Overview of Molecular Diagnostic Techniques and Instrumentation. In: RR Tubbs and MH Stoler (Eds.). Cell and Tissue Based Molecular Pathology. Churchill Livingstone, Philadelphia, 2009, p. 19-32.

[30] KM Elkins. Chapter 4 - DNA Extraction. In: KM Elkins (Eds.). Forensic DNA Biology. Academic Press, San Diego, California, 2013, p. 39-52.

[31] SA Thatcher. 3 - Nucleic Acid Isolation. In: N Rifai, AR Horvath and CT Wittwer (Eds.). Principles and Applications of Molecular Diagnostics. Elsevier, USA, 2018, p. 35-46. 